Inflammation in the middle ear mucosa, which can be provoked by different primary factors such as bacterial and viral infection, local allergic reactions and reflux, is the crucial event in the pathogenesis of otitis media with effusion (OME). Unresolved acute inflammatory responses or defective immunoregulation of middle inflammation can promote chronic inflammatory processes and stimulate the chronic condition of OME. Cytokines are the central molecular regulators of middle ear inflammation and can switch the acute phase of inflammation in the chronic stage and induce molecular-pathological processes leading to the histopathological changes accompanying OME. In this review we present cytokines identified in otitis media, immunoregulatory [interleukin (IL)-2, IL-10, transforming growth factorß]) and allergy associated (IL-4, IL-5, granulocytemacrophage colony-stimulating factor), as crucial molecular regulators, responsible for chronic inflammation in the middle ear and the chronic condition of OME.

Key words: Cytokines, Middle ear inflammation, Chronic otitis media

\section{The immunoregulatory and allergy-associated cytokines in the aetiology of the otitis media with effusion}

\author{
Marina G. Smirnova ${ }^{1, C A}$, John P. Birchall ${ }^{2}$ and \\ Jeffrey P. Pearson ${ }^{1}$
}

${ }^{1}$ School of Cell and Molecular Biosciences, University of Newcastle, The Medical School, Framlington Place, Newcastle upon Tyne, NE2 4HH, UK; and

${ }^{2}$ Department of Otorhinolaryngology, Queens

Medical Center, University Hospital, Nottingham, UK

${ }^{\mathrm{CA}}$ Corresponding author:
Tel: +441912226996
Fax: + +44 1912226706
E-mail: Marina.Smirnova@ncl.ac.uk

\section{Introduction}

The immunoregulatory cytokines [interleukin (IL)-2, IL-10, transforming growth factor (TGF)- $\beta$ ] and allergy-associated cytokines [IL-4, IL-5, granulocytemacrophage colony-stimulating factor (GM-CSF)] are mediators of the immune system, which are actively involved in regulation of molecular and cellular processes accompanying different types of inflammation.

IL-2 is the up-regulating cytokine, which stimulates primarily the cell-mediated inflammatory response by promoting growth, proliferation and differentiation of T cells, B cells, natural killer (NK) cells, monocytes and macrophages. It is secreted mainly by activated $\mathrm{T}$ cells. IL-2 induces activation and rapid clonal expansion of mature $\mathrm{T}$ cells, and cytokine production in $\mathrm{T}$ cells, including interferon (IFN) $\gamma$ and IL- $4 ;{ }^{1}$ growth of $\mathrm{B}$ cells and immunoglobulin (Ig) J-chain switching and secretion of $\operatorname{IgM}$ in $\mathrm{B}$ cells; $^{2}$ proliferation, production of IFN- $\gamma$ and cytolytic activity of NK cells; ${ }^{3}$ proliferation and differentiation of macrophage precursors; ${ }^{4}$ and cytolytic activity of monocytes. 5

In contrast to IL-2, IL-10 (known as the cytokine synthesis inhibitory and macrophage deactivating factor) down-regulates the immune reactions accompanying acute inflammation and limits the duration of inflammatory responses. IL-10 can also promote and regulate chronic inflammatory processes. IL-10 is produced by a variety of cell types, including $\mathrm{CD} 4^{+}$ T cells, activated $\mathrm{CD}^{+}{ }^{+} \mathrm{T}$ cells and activated $\mathrm{B}$ cells. The main anti-inflammatory activities of IL-10namely, inhibition of cytokine production in macrophages, neutrophils, $\mathrm{T}$ cells and NK cells, ${ }^{6-9}$ and inhibition of the macrophage-monocyte activation and the antigen presentation abilities of these cells ${ }^{10}$ - lead to the resolution of inflammation. However, if the acute inflammatory process has not been resolved, IL-10 can induce humoral inflammatory reactions such as the immunoglobulin isotype switching in B cells ${ }^{11,12}$ and differentiation of B cells into plasma cells, ${ }^{13}$ and thus promote switching of inflammation in the chronic stage.

TGF- $\beta$, produced by $\mathrm{T}$ cells, platelets and monocytes, plays an important role in regulation of the inflammatory processes and in tissue reparation. The effects of TGF- $\beta$ depend on the differentiation state of the responsive cells. ${ }^{14}$ TGF- $\beta$, as well as IL-10, participates in resolution of acute inflammation by inhibiting antigen presentation and cytokine production in macrophages, ${ }^{15}$ and suppressing proliferation of $\mathrm{T}$ cells and NK cells and cytokine production in activated T cells. ${ }^{14}$ Simultaneously, TGF- $\beta$ recruits monocytes to the site of inflammation and upregulates their pro-inflammatory activity; secretion of cytokines and growth factors, in particular. ${ }^{14}$ The contradictory effects of TGF- $\beta$ on monocyte/macrophage lineage, such as up-regulation of monocyte 
functions and deactivation of macrophages, demonstrate the highly coordinated role of TGF- $\beta$ in regulation of inflammatory responses.

The immunoregulatory and allergy-associated cytokine IL- 4 , produced by $\mathrm{CD} 4{ }^{+}{ }^{+} \mathrm{T}$ cells, mast cells and basophils, is actively involved in regulation of different types of inflammation. IL-4 up-regulates humoral inflammatory responses by inducing growth of B cells, isotype switching in activated B cells and differentiation of $\mathrm{B}$ cells into antibody producing plasma cells. ${ }^{16}$ IL-4 also stimulates the cell-mediated inflammatory processes by promoting growth of activated $\mathrm{T}$ cells ${ }^{17}$ and enhancing the development of virus-specific cytotoxic T cells. ${ }^{18}$ Simultaneously, IL-4 possesses powerful anti-inflammatory effects. In particular, IL-4 controls numerous molecular processes in monocytes, macrophages and neutrophils, which down-regulate production and secretion of the pro-inflammatory cytokines tumour necrosis factor (TNF)- $\alpha$, IL-1 and IL- $8,{ }^{19-21}$ deactivate inflammatory macrophages and lead to suppression of acute inflammation. IL-4 can also induce switching of acute inflammation in the chronic stage owing to its ability to up-regulate expression of the mannose receptor on activated macrophages. ${ }^{22}$ The mannose receptor promotes fusion of activated macrophages and formation of giant multinucleated cells in the zone of inflammation $^{23}$ that create the cellular background for manifestation of chronic inflammation.

IL-5 is an important regulator of the humoral immune response and is produced by $\mathrm{CD} 4^{+} \mathrm{T}$ cells as well as NK cells. ${ }^{24}$ Being a late regulating factor in differentiation of B cells, IL-5 plays an essential role in cytokine-induced production and secretion of immunoglobulins and supports humoral inflammatory reactions such as production and secretion of IgA. ${ }^{25}$ IL-5 is also the allergic cytokine, which by stimulating production, activation, differentiation and migration of eosinophils creates a strong molecular background for eosinophilic inflammation. ${ }^{26,27}$

GM-CSF regulates proliferation and maturation of granulocyte and macrophage precursors and activates mature neutrophils, eosinophils and macrophages, ${ }^{28}$ and thus participates in different types of inflammation. ${ }^{29}$ Monocytes, $\mathrm{T}$ cells, fibroblasts and endothelial cells activated by macrophage cytokines IL-1 $\beta$ or TNF- $\alpha$ produce GM-CSF. The GM-CSF enhances neutrophil phagocytosis, enhances release of chemotactic factors by neutrophils, ${ }^{30}$ induces production of the pro-inflammatory cytokines by macrophages and increases their function as antigen-presenting cells, ${ }^{31}$ and in this way promotes acute inflammatory reactions. In the presence of IL4, GM-CSF can initiate a specific differentiation of monocytes into osteoclast-like multinucleated giant cells $^{32}$ that create a background for chronic inflammation. GM-CSF can also contribute to allergic inflammation by promoting growth, prolonged survival and activation of eosinophils and basophils. ${ }^{33}$

Both groups of cytokines, the immunoregulatory IL-2, IL-10 and TGF- $\beta$ and the allergy-associated IL-4, IL-5 and GM-CSF, have been identified in otitis media and their presence is the evidence of their participation in regulation of local inflammatory processes. These cytokines can switch the acute phase of middle ear inflammation into the chronic stage and lead to the chronic condition of otitis media with effusion (OME).

\section{OME: a brief description}

OME, the commonest cause of childhood deafness in the developed world, is a chronic inflammatory condition of the middle ear cleft with repetitive recurrences of acute middle ear inflammation. The disease is characterized by a middle ear effusion that persists for months to years, cannot be cleared by the normal mucociliary transport mechanisms and is must usually removed by surgical operation.

A surgical procedure, which includes myringotomy, aspiration of fluid and the insertion of ventilation tubes (grommets) in the anterior tympanic membrane (Fig. 1), is the most effective option in treatment of OME. The main problem with ventilation tubes is secondary infection and post-operative otorrhea, which can be managed using antibiotic eardrops. ${ }^{34,35}$ However, increasing antibiotic resistance of bacterial pathogens ${ }^{36}$ and possible ototoxicity of topical antibiotics ${ }^{37}$ can complicate the antimicrobial therapy in post-surgical management of otitis media. Other non-surgical approaches in treatment and prophylaxis of OME include traditional methods, such as combined steroid-antimicrobial therapy $^{38,39}$ and polyvalent pneumococcal vaccination, ${ }^{40,41}$ and relatively new methods based on herbal medicine ${ }^{42,43}$ and homeopathy. ${ }^{44,45}$

The chronic condition of otitis media is associated with proliferative changes in the middle ear tissues, especially in the surface middle ear mucosa, which is presented in OME as a modified pseudostratified epithelium, ${ }^{46}$ where basal cells are differentiating into goblet cells, ${ }^{47}$ goblet cells are proliferating with enhanced secretory activity ${ }^{48}$ and formation of mucus glands occurs ${ }^{49,50}$ (Fig. 1).

Goblet cells produce and secrete mucins, which are important glycoproteins in the mucociliary transport system of the middle ear and are the main component of middle ear effusions, responsible for the viscous properties of effusions. ${ }^{51,52}$ However, under disease conditions, alterations that occur in the middle ear and eustachian tube mucin metabolism, ${ }^{53}$ in the structure of mucin glycoproteins ${ }^{54,55}$ and in the glycoconjugate expression in cilia and goblet cells ${ }^{56}$ promote the dysfunction of the normal 


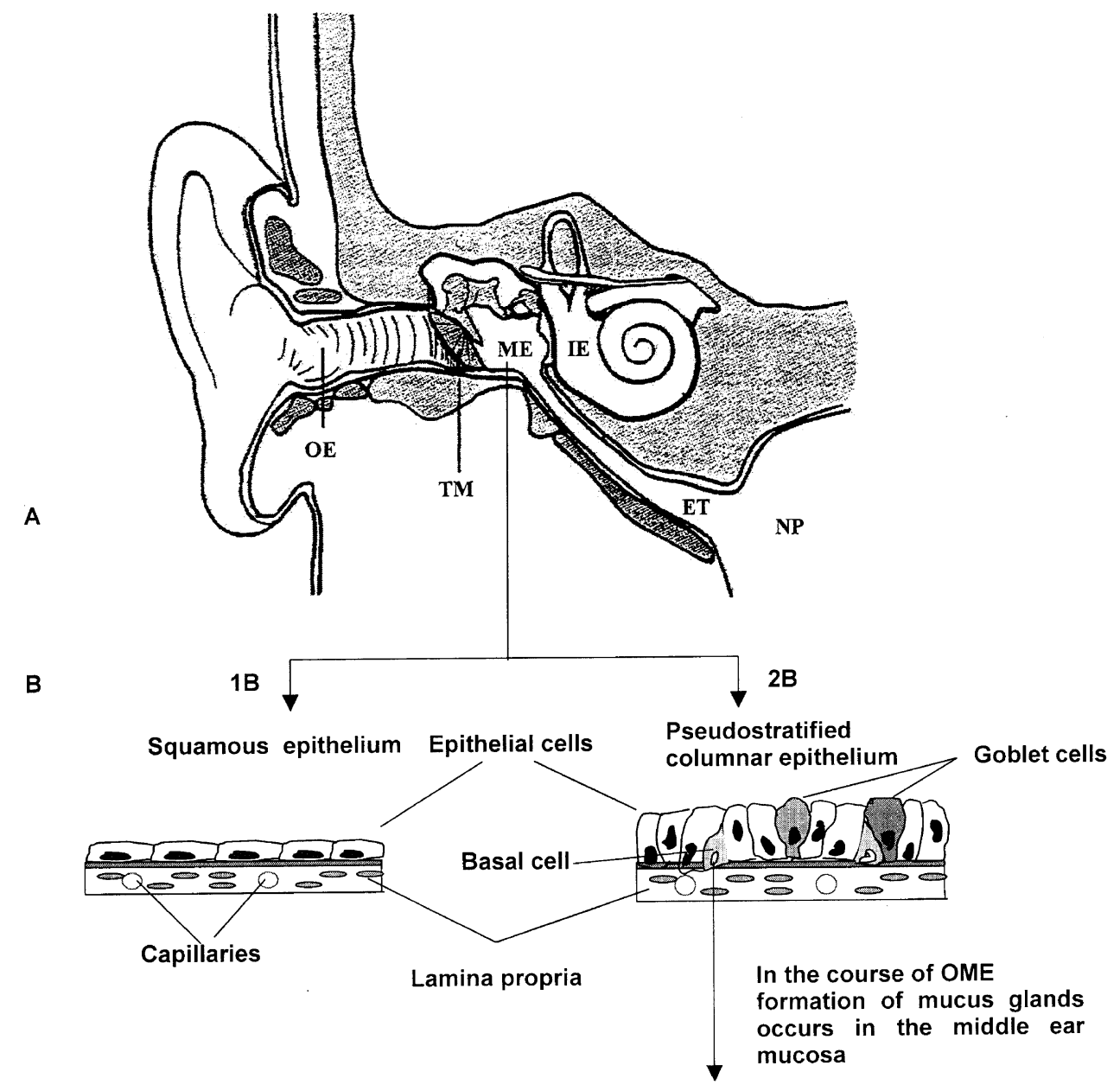

Mucin hypersecretion

C

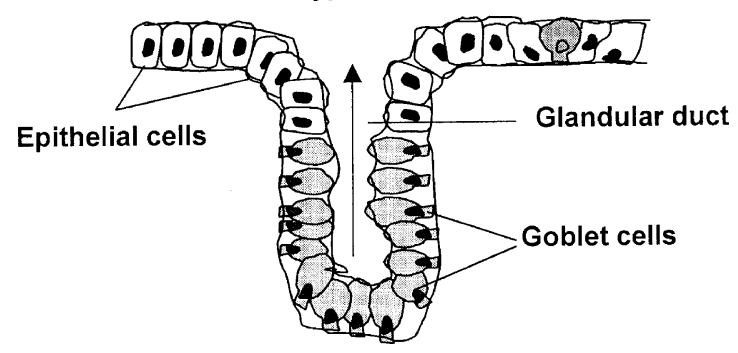

FIG. 1. Anatomy of the ear, schematic structure of the middle ear epithelium and mucus gland. (A) Anatomy of the ear: OE, outer ear; ME, middle ear; IE, inner ear; TM, tympanic membrane; ET, Eustachian tube; NP, nasopharynx. (B) There are two types of epithelium in the middle ear. The major part of middle ear is lined with simple squamous epithelium (1B). Near the Eustachian tube, epithelium of the middle ear is gradually transformed into pseudostratified columnar type (2B), some of which is ciliated. (C) Schematic structure of the mucus gland in the middle ear mucosa. Mucus glands develop as basal cells grow down into the lamina propria and differentiate into goblet cells.

mucociliary transport system and the formation of effusion in the middle ear cleft.

The expression of several mucins has been detected in OME. ${ }^{53,57}$ However, overproduction of only two mucins has been observed in otitis media; namely, the membrane-bound $\mathrm{MUC}^{53}$ and the secreted MUC5B. ${ }^{53,55,58,59}$ Another secreted mucin (MUC5AC) is always presented in effusions, but in varying amounts, ${ }^{3,55,57,60}$ and its levels maybe linked to levels of the pro-inflammatory cytokines TNF- $\alpha$, IL-6 and IL-8, which can promote different levels of MUC5AC secretion. ${ }^{61,62}$
The initial step in the pathogenesis of OME is the inflammatory process in the middle ear mucosa. Bacteria, ${ }^{63,64}$ viruses, ${ }^{65,66}$ allergic reactions ${ }^{67,68}$ and even gastroesophageal reflux ${ }^{69-71}$ in tandem with predisposing factors such as eustachian tube dysfunction, ${ }^{72}$ cleft palate $^{73}$ and obstructive adenoids ${ }^{74}$ can stimulate the middle ear inflammation.

Different groups of inflammatory mediators were identified in the human middle ear mucosa, fluids and effusions. A lot of different mediators participate in initiation and early stages of the middle ear inflammation, including arachidonic acid metabolites 
(prostaglandin $\mathrm{E}_{2}$ and leukotrienes LT-B 4, LT-C 4 ), ${ }^{75,76}$ histamine, ${ }^{77,78}$ platelet-activating factor, ${ }^{79}$ surface cell adhesion molecules (intercellular adhesion molecule1, vascular cell adhesion molecule-1, endothelial leukocyte adhesion molecule-1, platelet endothelial cell adhesion molecule), ${ }^{80,81}$ soluble cell adhesion molecules (soluble intercellular adhesion molecule-1 and soluble vascular cell adhesion molecule-1), ${ }^{82,83}$ chemokine RANTES, ${ }^{84}$ complement C3a anaphyla$\operatorname{toxin}^{85}$ and interferon- $\gamma{ }^{86}$

However, cytokines are the key mediators of the middle ear inflammation. Cytokines regulate different stages of inflammation, are responsible for resolution of inflammation and can initiate local molecular processes leading to histopathological changes in the middle ear mucosa and submucosa, and the chronic condition of otitis media. Different groups of cytokines have been identified in the middle ear effusions and mucosa: the pro-inflammatory TNF- $\alpha$, IL-1 $\beta$, IL- 6 and IL-8; the immunoregulatory IL-2, IL-10 and TGF- $\beta$; and the allergy-associated IL- 4 , IL- 5 and GM-CSF.

The pro-inflammatory cytokines and their participation in the pathogenesis of otitis media have been already discussed, ${ }^{87}$ and are more related to the acute phase of middle ear inflammation. In the present review we have analysed the immunoregulatory and the allergy-associated cytokines in otitis media, which, by providing the cellular and molecular background for the chronic inflammation in middle ear, promote the chronic condition of OME.

\section{The immunoregulatory cytokines IL-2, IL-10, TGF- $\beta$ and their cellular and molecular networks in OME}

\section{IL-2 in otitis media}

IL-2 has been detected in middle ear effusions from children with chronic OME at high concentration (greater than $300 \mathrm{pg} / \mathrm{ml}$ ). ${ }^{88}$ The analysis of peripheral blood immunologic pattern in patients with persistent middle ear effusions ${ }^{89,90}$ showed the following: (1) the number of $\mathrm{CD}^{+}$and $\mathrm{CD}^{+}{ }^{+} \mathrm{T}$ lymphocytes was decreased and the T-cell subset ratio $\left(\mathrm{CD}^{+}{ }^{+}\right.$/ $\mathrm{CD}^{+}$) was reduced; (2) proliferative responses of blood T cells were diminished; and (3) generation of IL-2 by peripheral blood lymphocytes was decreased. Another immunologic investigation of children with recurrent otitis media revealed a consistent inability of adenoidal $\mathrm{T}$ cells to turn on $\mathrm{B}$ cells to mature into immunoglobulin-secreting plasma cells that has been explained by defective production of IL-2 in adenoids. ${ }^{91}$ This assumption was confirmed by cytokine assay of IL-2, which has been done simultaneously in nasopharyngeal lymphoid tissues and in peripheral blood of children with recurrent otitis. The adenoidal lymphocytes produced significantly less IL-2 compared with the patient's peripheral blood lymphocytes. ${ }^{92}$ It has been assumed that poor production of IL-2 in adenoidal tissues is probably linked to a deficiency of IL-2 production in the middle ear tissues, and that could be associated with the persistence of OME. Thus, general and/or local deficiency of the IL-2 production could induce defective immunoregulation of the middle ear inflammation and promote the persistence of OME.

The investigation of IL-2 in experimental models of otitis media showed the involvement of IL-2 in regulation of acute inflammation because: (1) the IL-2 producing cells were predominant in acute OME compared with chronic OME, ${ }^{93}$ and (2) recombinant IL-2 trans-tympanically injected into the middle ear of normal guinea pigs caused the inflammatory middle ear effusion within $24 \mathrm{~h}$, which cleared by $72 \mathrm{~h}$ after inoculation. ${ }^{94}$ However, differing degrees of responsiveness of effusion production were observed following the instillation of IL-2 in the middle ear, ${ }^{95}$ varying from pronounced middle ear effusion causing rather severe mixed hearing loss to complete lack of effusion, and IL-2 was detected in all the middle ear effusions in experimental OME with signs of sensorineural hearing loss. ${ }^{96}$

By analysis of clinical and experimental data we can propose the following conclusions about the role of IL-2 in OME:

1. IL-2 is involved in regulation of the middle ear inflammation and, as the main T-cell growth and differentiation factor, IL-2 can support acute and chronic inflammatory processes in the middle ear.

2. IL-2 can regulate local acute inflammatory response by inducing activation, differentiation of $\mathrm{T}$ cells and production of the proinflammatory (IL-1 $\beta$, IL-6) and anti-inflammatory cytokines (IL-10, TGF- $\beta$ ) by activated T cells (Fig. 2).

3. The deficiency of local or general IL-2 production can suppress reactions of acute inflammation and promote persistence of OME, which can develop with time into the chronic OME (Fig. 3).

4. The excessive production of IL-2 can provoke chronic cell-mediated and (or) humoral inflammatory processes (proliferation of activated $\mathrm{T}$ cells, increased production of cytokines IL-4, IL-5 and GM-CSF by proliferated $\mathrm{T}$ cells, immunoglobulin-switching and IgM secretion in B cells), which will induce switching of the middle ear inflammation in the chronic stage with subsequent development of chronic OME (Fig. 3). 


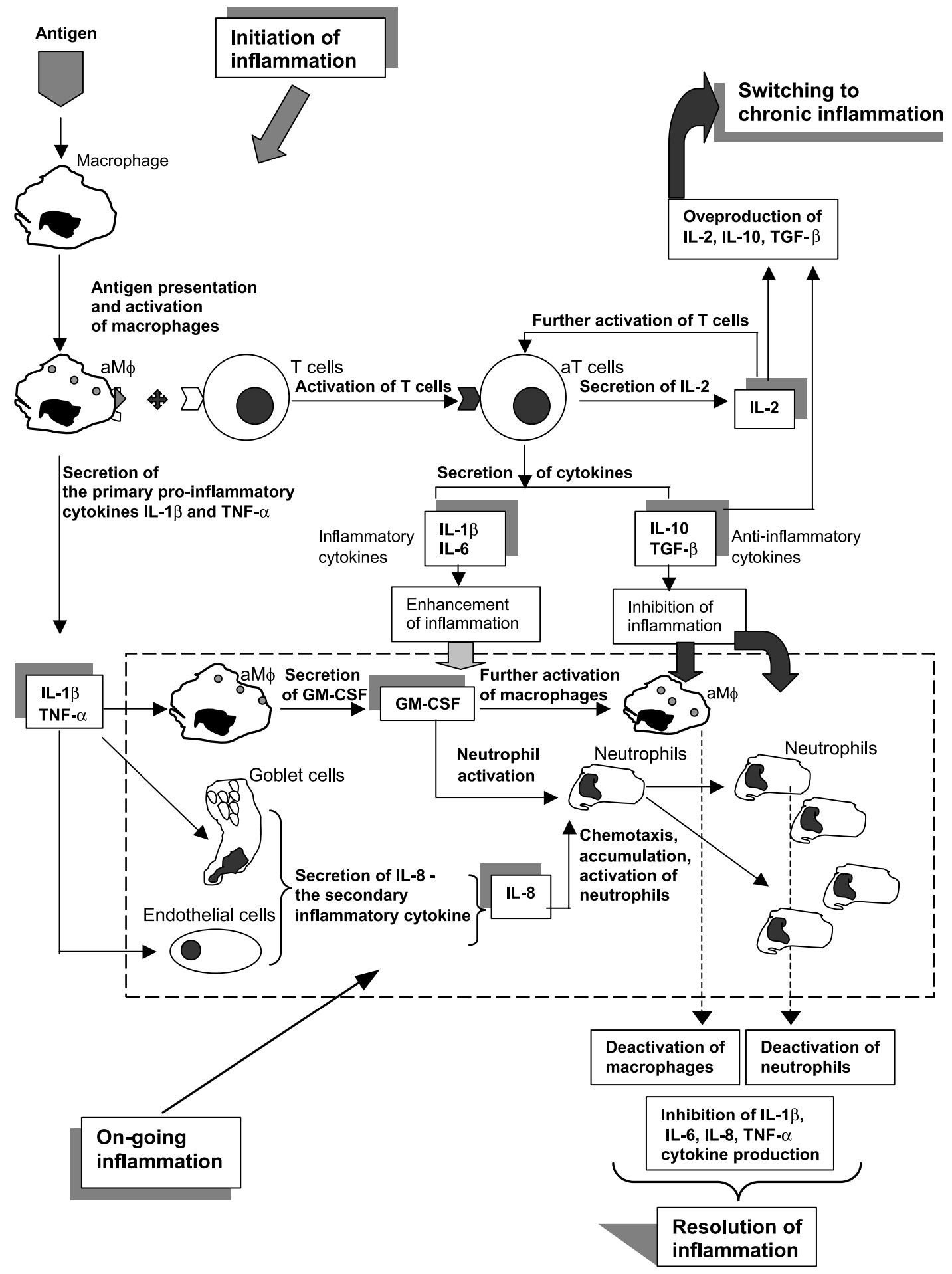

FIG. 2. Cytokine regulation of acute inflammatory response in the middle ear. Initiation of inflammation includes activation of macrophages, which, by presenting antigen, interact with T cells and induce the T-cell activation. The activated macrophages $(\mathrm{aM} \phi)$ produce the primary pro-inflammatory cytokines IL-1 $\beta$ and TNF- $\alpha$, which up-regulate secretion of IL-8 by goblet cells and endothelial cells and secretion of GM-CSF by activated macrophages. IL-8 and GM-CSF promote activation of neutrophils and macrophages - the main effector cells of acute inflammation. IL-8 induces chemotaxis and accumulation of neutrophils, and GM-CSF increases neutrophil phagocytosis and inflammatory activity of macrophages. Simultaneously the activated T cells (aTcells) produce many cytokines including IL-1 $\beta, I L-6, I L-2, I L-10$ and TGF- $\beta$. IL-2 enhances further activation and differentiation of T cells. IL-1 $\beta$ and IL- 6 join the ongoing inflammation and enhance it. IL-10 and TGF- $\beta$ keep under control inflammatory processes, and when the antigen is completely destroyed they inhibit activities of neutrophils and macrophage and production of the inflammatory cytokines IL-1 $\beta, \mathrm{IL}-6, \mathrm{IL}-8$ and TNF- $\alpha$, and thus provide resolution of inflammation. Overproduction of the immunoregulatory cytokines IL-2, IL-10 and TGF- $\beta$ in the course of middle ear inflammation will promote humoral and cell-mediated chronic processes and switching of inflammation in the chronic stage. 


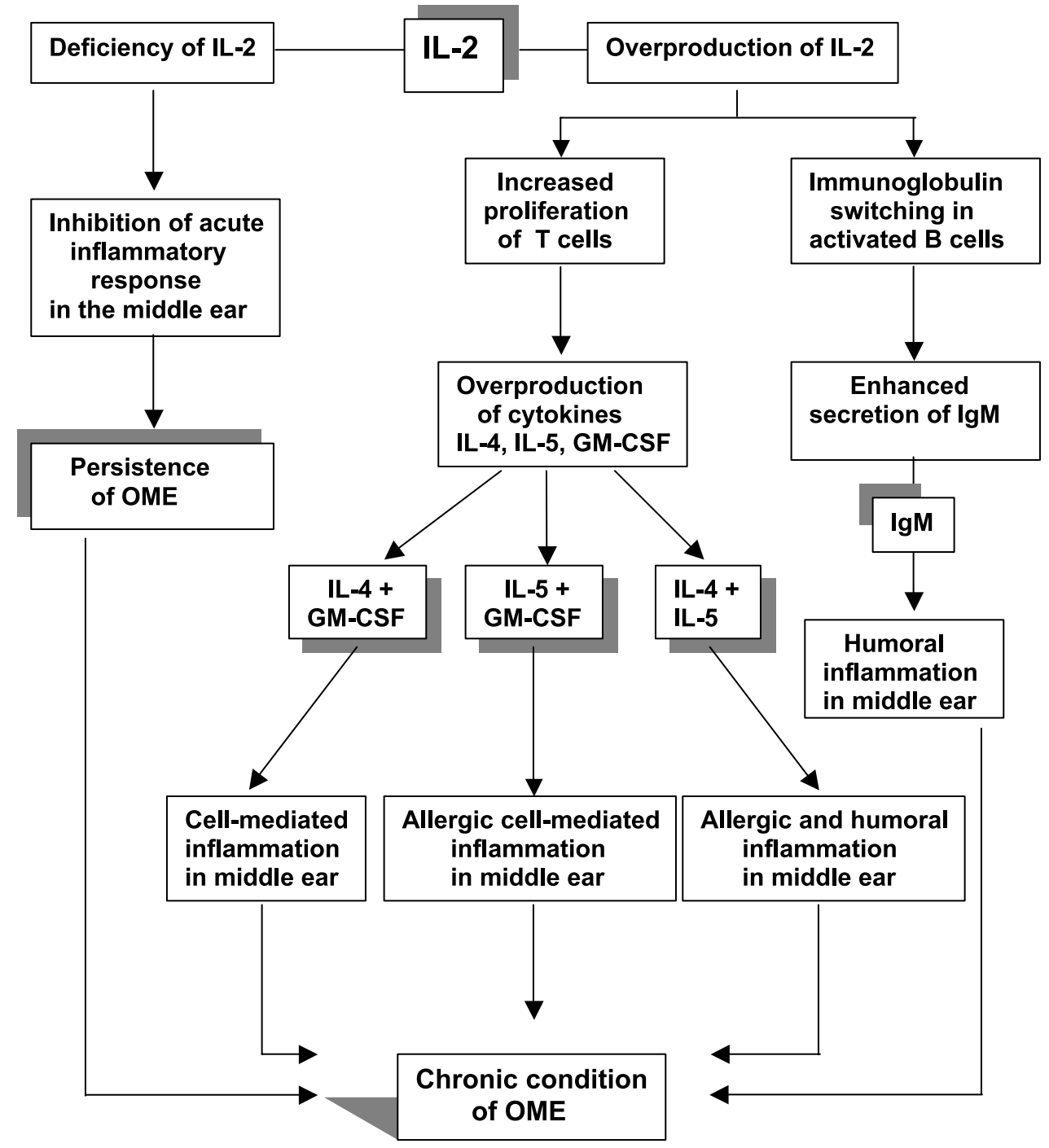

FIG. 3. Cellular and molecular consequences of the unbalanced production of IL-2 in the course of the middle ear inflammation leading to the chronic condition of OME.

\section{IL-10 in otitis media}

The clinical investigations demonstrated the involvement of IL-10 in chronic otitis media. ${ }^{97,98}$ IL-10 was identified in middle ear effusions from children undergoing tympanostomy tube placements and its mean concentration was $56 \pm 58.7 \mathrm{pg} / \mathrm{ml} .{ }^{97}$ It has been assumed that the presence of IL-10 in middle ear effusions might be one of the causes of a lack of clinical features of acute inflammation and could lead to a chronic inflammatory state. Chronic otitis media has been also associated with dysregulated local production of IL-10. ${ }^{98}$ Patients with chronic otitis media showed high levels of IL-10 ( > $100 \mathrm{pg} / \mathrm{ml})$ produced by sinus lavage cell culture and simultaneously low production of IL-10 by peripheral blood mononuclear cells.

Investigations of cytokine profiles in different experimental models of OME showed a rapid appearance of IL-10 in the early stages of acute otitis media ${ }^{9-103}$ and that IL-10 in mucosa was produced predominantly by $\mathrm{CD}^{+}{ }^{+} \mathrm{T}$ cells. ${ }^{104}$ Streptococcus pneumoniae induced expression of IL-10 mRNA in middle ear mucosa within 1-2 days after inoculation. ${ }^{99,100}$ Lipoteichoic acid, one of the components present within the cell wall layer of most Grampositive bacteria, ${ }^{101}$ and non-typeable Haemophilus influenzae (NTHi) ${ }^{102,103}$ induced the expression of IL-10 mRNA in middle ear mucosa even faster, within $6 \mathrm{~h}$ after inoculation. It is interesting to note that the expression of IL-10 mRNA followed the expression of TNF-a and IL- 6 mRNAs, ${ }^{99,100}$ and sometimes occurred simultaneously with the pro-inflammatory cytokines. ${ }^{101,102}$

Thus, clinical and experimental data about IL-10 in OME lead to the following conclusions:

1. IL-10 is involved in regulation of the middle ear inflammatory response induced by bacterial infection.

2. The expression of IL-10 in acute otitis media is up-regulated shortly after or even simul- 
taneously with the pro-inflammatory cytokines, TNF- $\alpha$ and IL-6. That is, the evidence of initiation of corrective immunoregulation in the middle ear mucosa, because IL-10 as the main anti-inflammatory cytokine, can down-regulate the local population of inflammatory cells, macrophages and neutrophils, and production of the proinflammatory cytokines TNF- $\alpha$, IL- $1 \beta$, IL-6, IL-8 and promote resolution of inflammation (Fig. 2).

3. If the acute inflammatory response is not resolved correctly, the prolonged presence of IL-10 in the zone of inflammation can provoke the amplification of chronic humoral inflammatory processes, such as increased secretion of immunoglobulins, especially IgA, by activated B cells and possible generation of plasma cells, in the presence of IL-4 (Fig. 4). In this way, IL-10 can contribute to switching of the disease into the chronic stage.

4. The deficiency of IL-10 in acute otitis media can also lead to chronic condition of OME, because shortage of IL-10 will promote overproduction of the inflammatory cytokines, especially IL- $1 \beta$, TNF- $\alpha$ and IL- 6 , which can induce tissue damage and irre- versible changes in the middle ear mucosa (Fig. 4).

General conclusions about the role of IL-2 and IL-10 in an aetiology of OME

Both cytokines, IL-2 and IL-10, participate in balanced immunoregulation of the middle ear inflammatory response. IL-2 up-regulates cellular and molecular events, accompanying acute inflammation, whereas IL-10 down-regulates acute inflammatory reactions and promotes resolution of inflammation. Any imbalance in production of these cytokines will induce chronic inflammatory processes (cellmediated or humoral, or both) or stimulate uncontrolled inflammatory-related damage of the middle ear tissues (Figs 3 and 4).

Thus, IL-2 and IL-10 can be considered as the key cytokine mediators, regulating switching of the acute phase of middle ear inflammation in the chronic stage, which will lead to the chronic condition of OME.

\section{TGF- $\beta$ in otitis media}

Clinical investigations of TGF- $\beta$ in OME showed its relation to chronic otitis media. ${ }^{105,106}$ The identification of TGF- $\beta$ in serous and mucoid middle ear effusions was associated with a history of previous

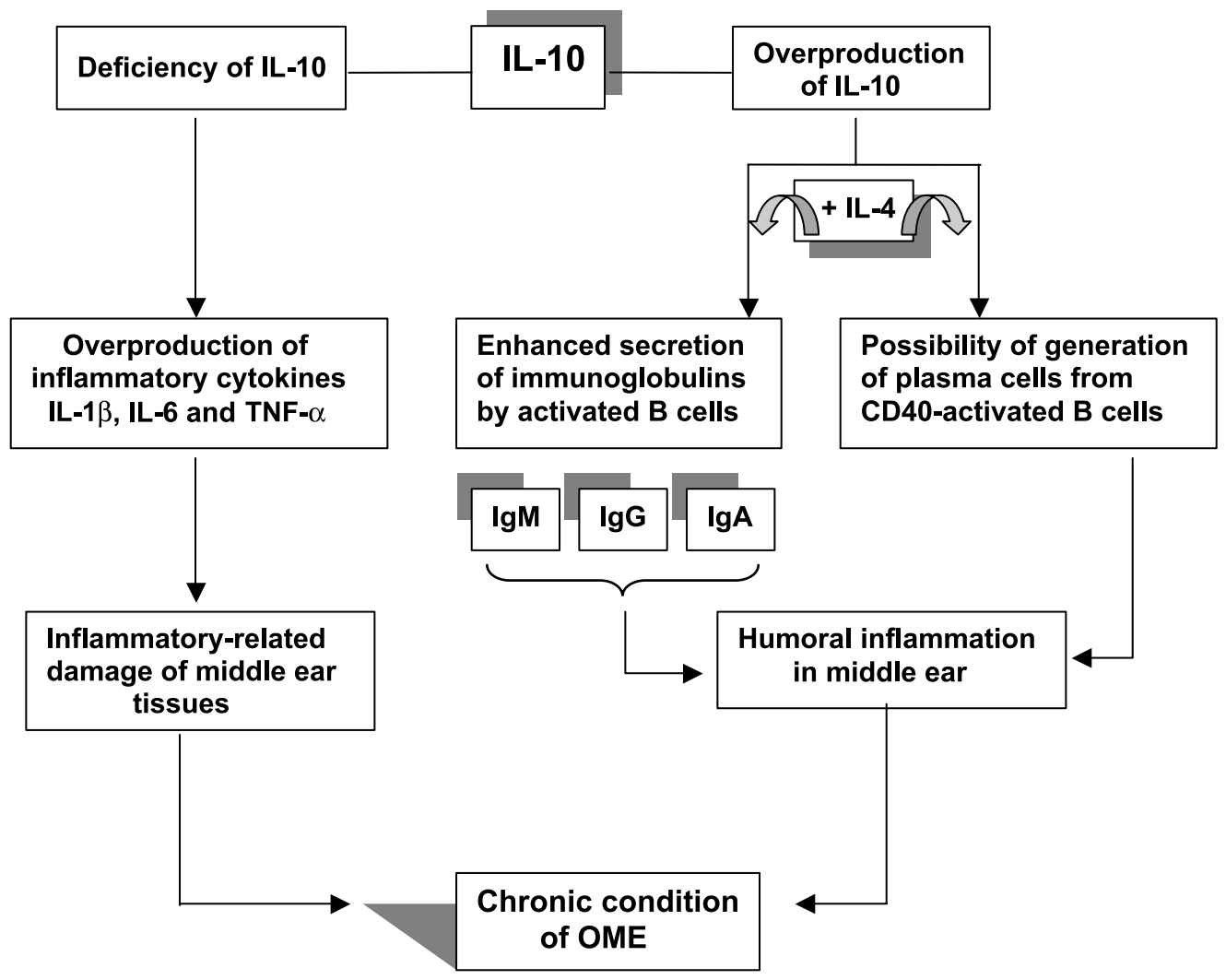

FIG. 4. Cellular and molecular consequences of the unbalanced production of IL-10 in the course of the middle ear inflammation leading to the chronic condition of OME. 
tympanostomy tube placements. ${ }^{105}$ Investigation of growth factors in tympanic membrane perforations showed that TGF- $\beta$ could promote development of the fibrotic scar at the perforation margin, explaining the deficient healing pattern of tympanic membranes in chronic otitis media. ${ }^{106}$

However studies of cytokines in experimental OME demonstrated the presence of TGF- $\beta$ also in acute otitis media. ${ }^{100,102,103}$ The expression of TGF- $\beta$ mRNA was up-regulated in acute otitis media caused by $S$. pneumoniae ${ }^{100,102}$ and NTHi infections, ${ }^{102,103}$ and was detected early during the course of acute inflammation, within $24 \mathrm{~h}$ after inoculation, together with cytokines IL-1, TNF-a and IL-10. However, the highest mRNA levels for TGF- $\beta$ were recorded considerably later, on days 6 and 28, for the NTHiinfected and pneumococcus-infected animals, respectively, and its expression continued even after resolution of acute otitis media. ${ }^{102}$

TGF- $\beta$ regulates host response in infectious diseases through the TGF- $\beta$-activated kinase $1^{107}$ and TGF- $\beta$-Smad signaling pathway. ${ }^{108}$ It has been shown that NTHi, a major human bacterial pathogen of otitis media, strongly induced up-regulation of MUC5AC mucin in human epithelial cells. This induction occurred via activation of the Toll-like receptor 2MyD88-dependent p38 mitogen-activated protein kinase (MAPK) pathway. However, activation of TGF- $\beta$-Smad signaling by TGF- $\beta$ resulted in downregulation of p38 MAPK by inducing MAPK phophatase-1, and subsequent down-regulation of MUC5AC transcription. ${ }^{108}$ TGF- $\beta$ thereby acted as a negative regulator of MUC5AC mucin gene expression. This is a very significant fact in understanding the role of TGF- $\beta$ in otitis media, because varying levels of the secreted mucin MUC5AC are presented in the middle ear mucosa and effusions in patients with OME. ${ }^{53,55,57}$

By analysis of these data we can make the following conclusions about the role of TGF- $\beta$ in OME:

1. TGF- $\beta$ participates in regulation of the middle ear inflammation.

2. TGF- $\beta$ is a negative regulator of acute inflammation in the middle ear. Early activation of TGF- $\beta$ together with another antiinflammatory cytokine, IL-10, in the course of acute otitis media demonstrates the involvement of TGF- $\beta$ in the correct resolution of acute inflammatory response. TGF- $\beta$ as well as IL-10 can inactivate macrophages and inhibit pro-inflammatory cytokine production at the site of inflammation (Fig. 2).

3. TGF- $\beta$ can be also involved in down-regulation of bacterial-induced MUC5AC mucin production, and that is the additional evi- dence for TGF- $\beta$ as a negative regulator of the acute middle ear inflammation.

4. The high level of TGF- $\beta$ expression detected on later stages of the middle ear inflammation and after shows participation of TGF- $\beta$ in repair of damaged tissues.

5. The presence of TGF- $\beta$ in chronic otitis media demonstrates the involvement of TGF- $\beta$ in regulation of chronic inflammatory response in the middle ear. The overproduction of TGF- $\beta$ can promote chronic inflammatory processes in the middle ear, both cell-mediated and humoral (Fig. 5). The cellmediated response, induced by TGF- $\beta$, can develop in the following way: excessive accumulation of monocytes activated by TGF- $\beta$ leads to excessive amount of macrophages and their activation in the presence of GM-CSF. These activated macrophages in the zone of inflammation, in the presence of IL-4, can fuse and generate the multinucleated giant cells, which are the cellular background for chronic inflammation. Humoral inflammatory processes, which can be up-regulated by TGF- $\beta$, include the increased secretion of immunoglobulins, IgA in particular, especially in the presence of IL10 .

6. The prolonged expression of TGF- $\beta$ in the zone of inflammation can lead to excessive accumulation of fibroblasts and result in progressive fibrosis, which is analogous to unregulated tissue repair.

Thus, TGF- $\beta$ can contribute to the pathogenesis and persistence of chronic OME in many ways.

\section{The allergy-associated cytokines IL-4, IL-5 and GM-CSF and their cellular and molecular networks in OME}

\section{IL-4 in otitis media}

IL-4 was identified in the middle ear effusions of children with persistent $\mathrm{OME}^{109}$ and in atopic children with OME undergoing myringotomy and ventilation tube placement. ${ }^{110}$ The cytokine analysis of effusions showed a higher mean level of IL- 4 in the allergy-positive group compared with the allergynegative group ${ }^{109}$ and a higher percentage of cells expressing IL-4 in atopic patients with OME compared with that seen in non-atopic patients. ${ }^{110} \mathrm{~A}$ higher level of IL- 4 in effusions correlated with predominance of $\mathrm{T}$ lymphocytes, which was the sign of chronic inflammation and was also related to the atopic background of patients with OME. ${ }^{110}$ In effusions of non-atopic patients, the level of IL-4 was 


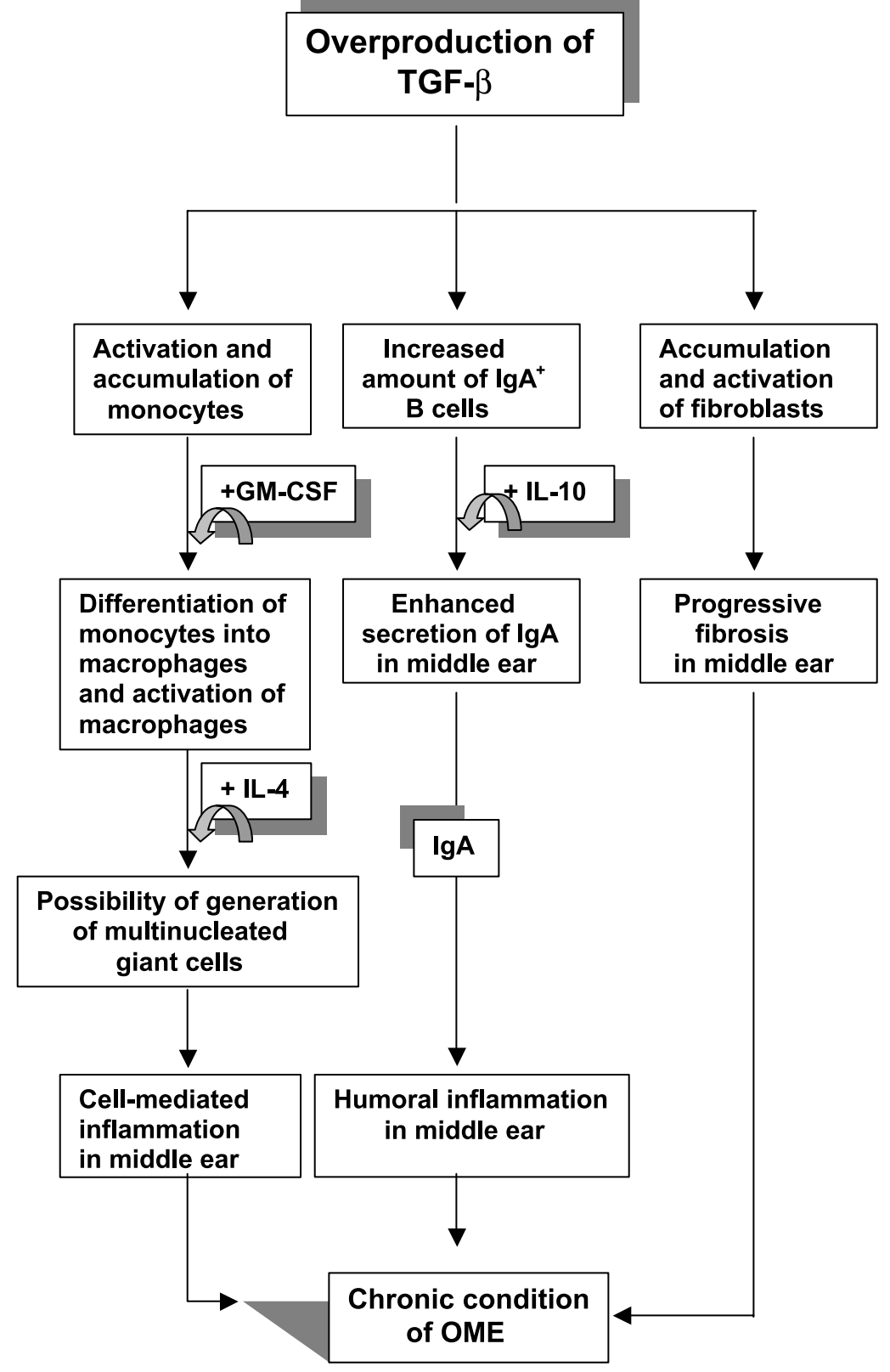

FIG. 5. Consequences of the overproduction of TGF- $\beta$ in the course of the middle ear inflammation.

lower and the predominance of neutrophils ${ }^{109}$ demonstrated signs of an acute inflammatory response.

Investigation of adenoids in patients with recurrent otitis media ${ }^{92,111}$ resulted in the following important findings: (1) expression and secretion of IL-4 was detected in adenoids; (2) adenoidal lymphocytes produced the same level of IL-4, or even slightly more, compared with the patient's peripheral blood lymphocytes; ${ }^{92}$ and (3) the epsilon germline transcripts for $\operatorname{IgE}$ were detected in the adenoids and the level of IgE epsilon germline transcript expression was dependent on the level of IL-4 mRNA expression. ${ }^{111}$ This local IL-4-induced immunoglobulin class switching to IgE in the adenoids was considered the essential molecular process contributing to chronic inflammation in the middle ear and promoting the pathogenesis and persistence of OME.

Thus, IL- 4 was presented in both groups of patients with OME, allergic and non-allergic. However, local overproduction of IL-4 was associated predominantly with an allergic background of patients.

Studies on IL-4 in experimental OME ${ }^{93,112}$ demonstrated the involvement of IL-4 in regulation of different types of otitis media. In trans-tympanically challenged animals the expression of IL-4 was detected during acute and chronic otitis media, with the predominance of $\mathrm{IL}_{-} 4^{+}$cells in the acute form. ${ }^{93}$ The trans-tympanical injection of soluble receptors 
for IL-4 prevented the allergic Eustachian tube dysfunction and formation of effusion in the middle ear cleft. $^{112}$

The involvement of IL- 4 in regulation of MUC5AC and MUC5B mucin gene expression and secretion has been shown in human airways. ${ }^{113-115}$ The secreted mucins, MUC5AC and MUC5B, are presented in the middle ear mucosa and effusions in patients with chronic OME. ${ }^{53,55,57-60}$ Although relationships between IL-4 and production of MUC5AC and MUC5B mucins in the course of otitis media have not been investigated, the ability of a soluble receptor for IL-4 to prevent Eustachian tube dysfunction and formation of effusions in the middle ear cleft ${ }^{112}$ demonstrated the potential involvement of IL- 4 in the regulation of the middle ear mucin metabolism.

All these data allow us to make the following conclusions about the role of IL- 4 in OME:

1. IL-4 is involved in regulation of different types of otitis media.

2. IL-4 is one of the cytokines responsible for an allergic type of inflammation owing its ability to induce local immunoglobulin class switching to IgE (Fig 6).

3. IL-4 can support local humoral inflammatory responses by increasing production and secretion of immunoglobulins in activated B cells (Figs 4 and 6).

4. IL-4 can also support cell-mediated chronic inflammation in the middle ear by promoting generation of multinucleated giant cells (Figs 5 and 6), although it is necessary to note that giant cells in OME have not been investigated.

5. IL-4 can also participate in the regulation of mucin metabolism and the mucociliary transport system in middle ear inflammation.

Thus, IL- 4 is the important regulator of cellular and molecular processes, accompanying different types and different stages of the middle ear inflammation, and an important factor contributing to chronic condition and persistence of OME.

\section{IL-5 in otitis media}

IL-5 was detected in the middle ear mucosa and effusions in atopic patients with persistent OME. ${ }^{110,116,117}$ The expression of IL-5 mRNA in mucosa was up-regulated and correlated with increased expression of major basic protein (cell marker for eosinophils) and CD3 (cell marker for activated $\mathrm{T}$ lymphocytes). ${ }^{116}$ Examination of the cytokine profile in the middle-ear specimens showed an increased number of cells expressing IL- 5 and its correlation with the percentage of eosinophils and $\mathrm{T}$ lymphocytes. ${ }^{110}$ Correlation between the percentage of eosinophils and levels of IL-5 in effusions was particularly striking in OME patients with asthma, ${ }^{117}$ suggesting that middle ear eosinophilia could be dependent not only on the local, but also on the general level of IL-5 production. The percentage of cells expressing IL- 5 in effusions of atopic patients was the same or slightly higher compared with cells expressing IL- $4 ;{ }^{110}$ this was evidence that both cytokines IL-5 and IL-4 contributed to development of allergic inflammation in the middle ear.

Thus, overproduction of IL- 5 in OME is associated with the atopic background of patients, and IL-5 together with IL-4 is responsible for an allergic type of inflammation in the middle ear (Fig. 6). This assumption was confirmed in an experimental model of OME, ${ }^{112}$ where the late-phase allergic inflammatory response was prevented by pretreatment with IL5 antibodies or soluble receptors for IL-4.

However, the involvement of IL-5 in regulation of the non-allergic inflammatory response in the middle ear should not be ignored. The production of IL- 5 was detected in effusions of non-atopic patients with OME, ${ }^{110,117}$ although it was significantly less compared with atopic patients. Analysis of immunoregulatory cytokines in experimental models of $\mathrm{OME}^{93}$ demonstrated the absence of IL- 5 in acute otitis media and significant up-regulation of IL-5 production in chronic otitis media, where IL- $5^{+}$cells were numerous. Thus, the presence of IL-5 in OME of nonallergic patients shows the involvement of IL-5 in regulation of non-allergic chronic inflammatory reactions in the middle ear, where IL-5 can support humoral processes such as increased production and secretion of immunoglobulins, IgA in particular (Fig. 6)

Thus, IL- 5 can be considered the late mediator of middle ear inflammatory response, regulating allergic inflammation and increasing humoral inflammatory processes, which contribute to the chronic condition of OME.

\section{GM-CSF in otitis media}

Our knowledge about GM-CSF in OME is insufficient. However, the involvement of GM-CSF in regulation of middle ear inflammation has been shown as GMCSF was identified in effusions of acute purulent and chronic otitis media. ${ }^{118}$ The level of GM-CSF in acute otitis media was higher compared with the chronictype otitis media.

Despite a lack of experimental data about GM-CSF in OME, this cytokine could participate in regulation of different stages of the middle ear inflammation. GM-CSF was identified in acute otitis media, where it could activate matured neutrophils and macrophages and support the acute inflammatory response (Fig. 2).

GM-CSF in the presence of IL- 4 can induce monocyte differentiation towards generation of mul- 


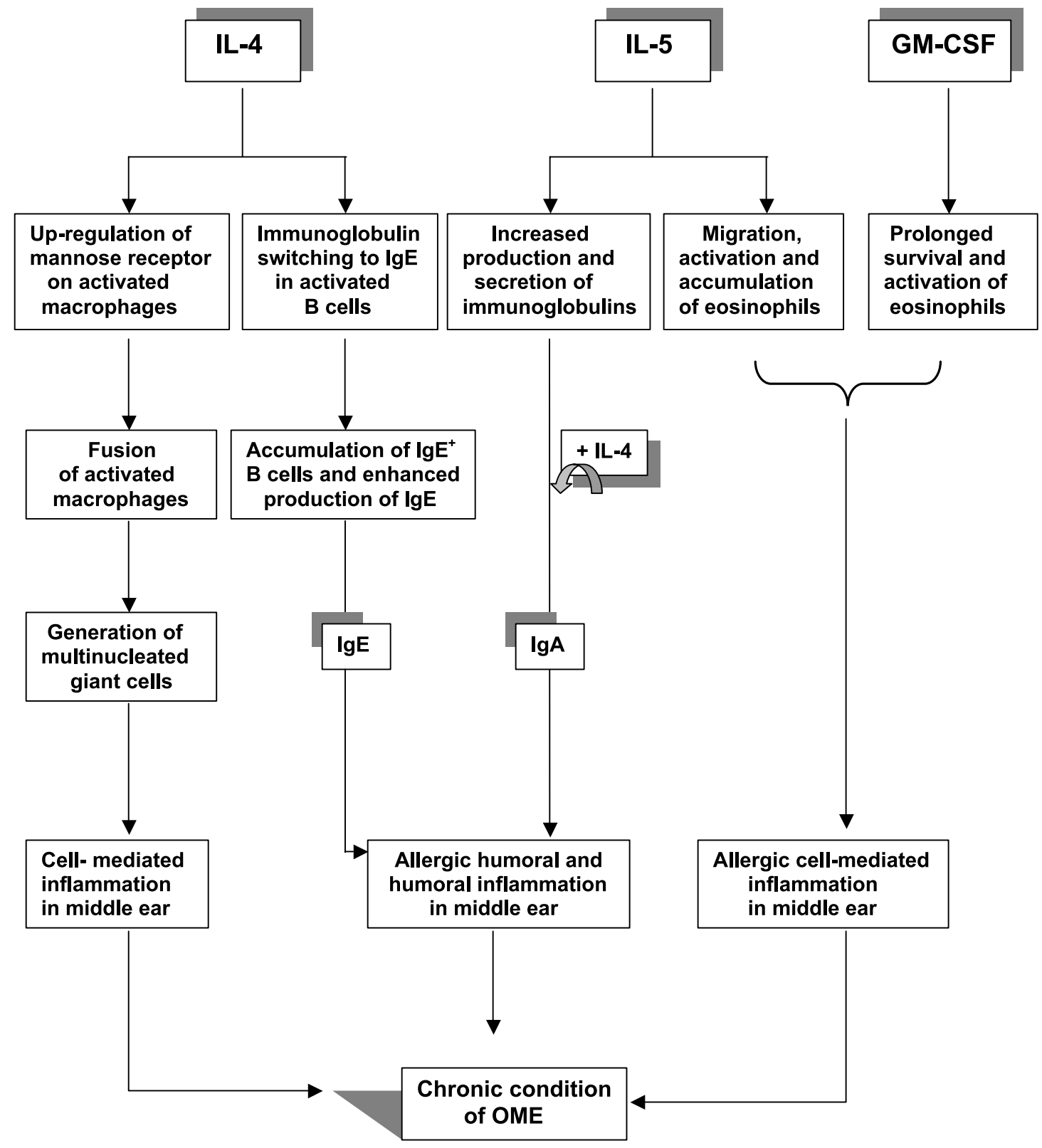

FIG. 6. Cellular and molecular networks of the allergy-associated cytokines leading to the chronic condition of OME.

tinucleated giant cells, and in this way create the cellular background for chronic middle ear inflammation (Fig. 5).

Finally, GM-CSF being the eosinophil survivalpromoting cytokine together with IL-5 can up-regulate allergic eosinophil-mediated inflammation in the middle ear (Fig. 6). However, in the past year of investigations GM-CSF has been shown as a potential down-regulator of allergic inflammation, because GM-CSF induced apoptosis of human eosinophils through the eosinophil receptor Siglec-8 (sialic acid binding immunoglobulin-like lectin). ${ }^{119}$

Thus, GM-CSF can be a very important regulator of the middle ear inflammation and additional experimental work needs to be done to clarify the exact role of this cytokine in the pathogenesis of chronic OME.

\section{Immunoglobulins in chronic OME}

Different types of immunoglobulins, namely IgM, IgG, IgA, secretory IgA and IgE, have been identified in effusions and middle ear fluid of chronic OME. ${ }^{120-123}$ The effusion level of IgM in some patients with chronic otitis media was markedly elevated. ${ }^{120}$ The mucoid type of effusions contained a high level of IgG, IgA ${ }^{121}$ and IgE. ${ }^{124}$ Comparison of the immunoglobulin levels measured in effusions and in sera showed that, in many cases, the effusion level of secretory $\operatorname{IgA}^{122}$ and $\operatorname{IgE}^{125}$ was significantly higher than the corresponding serum level, and this was the evidence of local overproduction of immunoglobulins in the middle ear.

The immunologic investigation of effusions detected the immune complexes of $\operatorname{IgG}(\operatorname{IgG}-\mathrm{ICs})$ and 
IgA (IgA-ICs) in both acute and chronic otitis media. ${ }^{126,127}$ The highest level of IgG-ICs was found in subacute cases, whereas IgA-ICs were predominant in chronic OME. The immunoglobulin immune complexes provided the prolongation of inflammatory process in the middle ear.

The presence of immunoglobulins in chronic OME was associated mainly with the bacterial infection. ${ }^{128-131} \operatorname{IgG}$ and IgA antibodies specific to Hemophilus influenzae and S. pneumoniae, ${ }^{128} \mathrm{IgG}$, IgM, IgA and secretory IgA antibodies specific to outer membrane antigens of Moraxella catarrhalis, ${ }^{129}$ and Staphylococcus aureus-harboured bacteria, intensely coated with secretory IgA and IgG antibodies, ${ }^{130,131}$ were identified in chronic effusions. Only one type of immunoglobulins, the secretory IgA, was identified in effusions infected with respiratory viruses. ${ }^{132}$

The presence of IgE in chronic OME has not been always associated with local allergic inflammation. ${ }^{124,133}$ However, local overproduction of $\mathrm{IgE}$ was usually accompanied by local allergic reactions, such as degranulation of mast cells found in the middle ear biopsy specimens ${ }^{124}$ and expression of IgE on mast cells detected in nasal mucosa specimens from patients with OME. ${ }^{134}$

Thus, the activity of immunoglobulins in chronic OME is evidence of chronic humoral inflammatory processes in the middle ear, which is obviously controlled by cytokines. Correlation between the levels and types of immunoglobulins and the immunoregulatory and allergy-associated cytokines in chronic OME has not been investigated. However, the presence of the main types of immunoglobulins, IgM, IgG, IgA, secretory IgA and IgE, in effusions is indirect evidence that cytokines IL-2, IL-10, TGF- $\beta$, IL4 and IL-5, which are involved in regulation of immunoglobulin production and secretion in general, ${ }^{2,11,12,16,25}$ participate also in local production and secretion of immunoglobulins and regulate humoral immune reactions during the course of middle ear inflammation (Figs 3-6).

\section{Concluding remarks}

The immunoregulatory cytokines and the allergyassociated cytokines can be considered the key regulators of the middle ear inflammation responsible for the molecular and cellular background of chronic OME.

The immunoregulatory cytokines IL-2, IL-10 and TGF- $\beta$ initiate and support molecular switching of the acute phase of inflammation in the chronic stage, whereas the allergy-associated cytokines IL-4, IL-5 and GM-CSF very probably provide the molecular and cellular background for chronic humoral, cell- mediated and allergic inflammatory processes in the middle ear, which lead to the chronic condition of OME.

However, it is necessary to note that additional experimental work needs to be done in order: (1) to elucidate the molecular mechanisms of cytokine regulation of the middle ear inflammation; and (2) to analyse the possibility of anti-cytokine therapy in clinical treatment of OME.

ACKNOWLEDGEMENTS. The authors gratefully acknowledge the Hearing Research Trust for the financial support.

\section{References}

1. Smith KA. Interleukin-2. Curr Opin Immunol 1992; 4: 271-276.

2. Jelinek DF, Lipsky PE. Regulation of human B lymphocyte activation, proliferation, and differentiation. Adv Immunol 1987; 40: 1-59.

3. Trinchieri G, Matsumoto-Kobayashi M, Clark SC, Seehra J, London L, Perussia B. Response of resting human peripheral blood natural killer cells to interleukin 2. J Exp Med 1984; 160: 1147-1169.

4. Baccarini M, Schwinzer R, Lohmann-Matthes ML. Effect of human recombinant IL-2 on murine macrophage precursors. Involvement of a receptor distinct from the p55 (Tac) protein. J Immunol 1989; 142: $118-125$.

5. Malkovsky M, Loveland B, North M, et al. Recombinant interleukin-2 directly augments the cytotoxicity of human monocytes. Nature 1987; 325: $262-265$

6. Fiorentino DF, Zlotnik A, Mosmann TR, Howard M, O'Garra A. IL-10 inhibits cytokine production by activated macrophages. J Immunol 1991; 147: 3815-3822.

7. Wang P, Wu P, Anthes JC, Siegel MI, Egan RW, Billah MM. Interleukin-10 inhibits interleukin-8 production in human neutrophils. Blood 1994; 83: $2678-2683$.

8. Fiorentino DF, Zlotnik A, Vieira P, et al. IL-10 acts on the antigenpresenting cell to inhibit cytokine production by Th1 cells. J Immunol 1991; 146: 3444-3451.

9. D'Andrea A, Aste-Amezaga M, Valiante NM, Ma X, Kubin M, Trinchieri G. Interleukin 10 (IL-10) inhibits human lymphocyte interferon gammaproduction by suppressing natural killer cell stimulatory factor/IL-12 synthesis in accessory cells. J Exp Med 1993; 178: 1041-1048.

10. Ho AS, Moore KW. Interleukin-10 and its receptor. Ther Immunol 1994; 1: $173-185$

11. Rousset F, Garcia E, Defrance T, et al. Interleukin 10 is a potent growth and differentiation factor for activated human B lymphocytes. Proc Natl Acad Sci USA 1992; 89: 1890-1893.

12. Defrance T, Vanbervliet B, Briere F, Durand I, Rousset F, Banchereau J. Interleukin 10 and transforming growth factor beta cooperate to induce anti-CD40-activated naive human B cells to secrete immunoglobulin A. J Exp Med 1992; 175: 671-682.

13. Rousset F, Peyrol S, Garcia E, et al. Long-term cultured CD40-activated B lymphocytes differentiate into plasma cells in response to IL-10 but not IL-4. Int Immunol 1995; 7: 1243-1253.

14. Letterio JJ, Roberts AB. Regulation of immune responses by TGF-beta. Annu Rev Immunol 1998; 16: 137-161.

15. Tsunawaki S, Sporn M, Ding A, Nathan C. Deactivation of macrophages by transforming growth factor-beta. Nature 1998; 334: 260-262.

16. Brown MA, Hural J. Functions of IL- 4 and control of its expression. Crit Rev Immunol 1997; 17: 1-32.

17. Spits H, Yssel H, Takebe Y, et al. Recombinant interleukin 4 promotes the growth of human T cells. J Immunol 1987; 139: 1142-1147.

18. Horohov DW, Crim JA, Smith PL, Siegel JP. IL-4 (B cell-stimulatory factor 1) regulates multiple aspects of influenza virus-specific cellmediated immunity. J Immunol 1988; 141: 4217- 4223.

19. Hart PH, Vitti GF, Burgess DR, Whitty GA, Piccoli DS, Hamilton JA Potential antiinflammatory effects of interleukin 4: suppression of human monocyte tumor necrosis factor alpha, interleukin 1 , and prostaglandin E2. Proc Natl Acad Sci USA 1989; 86: 3803-3807.

20. Wertheim WA, Kunkel SL, Standiford TJ, et al. Regulation of neutrophilderived IL-8: the role of prostaglandin E2, dexamethasone, and IL-4. $J$ Immunol 1993; 151: 2166-2175.

21. Dayer JM, Burger D. Interleukin-1, tumor necrosis factor and their specific inhibitors. Eur Cytokine Network 1994; 5: 563-571.

22. Raveh D, Kruskal BA, Farland J, Ezekowitz RA. Th1 and Th2 cytokines cooperate to stimulate mannose-receptor-mediated phagocytosis. $J$ Leukoc Biol 1998; 64: 108-113.

23. Dugast C, Gaudin A, Toujas L. Generation of multinucleated giant cells by culture of monocyte-derived macrophages with IL-4. J Leukoc Biol 1997; 61: $517-521$. 
24. Koike M, Takatsu K. IL-5 and its receptor: which role do they play in the immune response? Int Arch Allergy Immunol 1994; 104: 1-9.

25. Salvi S, Holgate ST. Could the airway epithelium play an important role in mucosal immunoglobulin A production? Clin Exp Allergy 1999; 29 $1597-1605$.

26. Sanderson CJ. Eosinophil differentiation factor (interleukin-5). Immunol Ser 1990; 49: 231-256.

27. Hogan SP, Foster PS. Cellular and molecular mechanisms involved in the regulation of eosinophil trafficking in vivo. Med Res Rev 1996; 16 $407-432$.

28. Baldwin GC. The biology of granulocyte-macrophage colony-stimulating factor: effects on hematopoietic and nonhematopoietic cells. Dev Biol 1992; 151: 352-367.

29. Feghali CA, Wright TM. Cytokines in acute and chronic inflammation. Front Biosci 1997; 2: d12-d26.

30. Ruef C, Coleman DL. Granulocyte-macrophage colony-stimulating factor: pleiotropic cytokine with potentialclinical usefulness. Rev Infect Dis 1990; 12: 41-62.

31. Bergamini A, Bolacchi F, Bongiovanni B, et al. Granulocyte-macrophage colony-stimulating factor regulates cytokine production in cultured macrophages through CD14-dependent and -independent mechanisms. Immunology 2000; 101: 254-261.

32. Akagawa KS, Takasuka N, Nozaki Y, et al. Generation of CD1+RelB + dendritic cells and tartrate-resistant acid phosphatase-positive osteoclast-like multinucleated giant cells from human monocytes. Blood 1996; 88: 4029-4039.

33. Hirai K, Miyamasu M, Takaishi T, Morita Y. Regulation of the function of eosinophils and basophils. Crit Rev Immunol 1997; 17: 325-352.

34. Younis RT, Lazar RH, Long TE. Ventilation tubes and prophylactic antibiotic eardrops. Otolaryngol Head Neck Surg 1992; 106: 193-195.

35. Bluestone CD. Role of surgery for otitis media in the era of resistant bacteria. Pediatr Infect Dis J 1998; 17: 1090-1098, discussion 10991100 .

36. Dagan R. Clinical significance of resistant organisms in otitis media. Pediatr Infect Dis J 2000; 19: 378-382.

37. Morpeth JF, Bent JP, Watson T. A comparison of cortisporin and ciprofloxacin otic drops as prophylaxis against post-tympanostomy otorrhea. Int J Pediatr Otorbinolaryngol 2001; 61: 99-104.

38. Salam MA, Cable HR. The use of antibiotic/steroid ear drops to reduce post-operative otorrhoea and blockage of ventilation tubes. A prospective study. J Laryngol Otol 1993; 107: 188-189.

39. Rosenfeld RM. Nonsurgical management of surgical otitis media with effusion. J Laryngol Otol 1995; 109: 811-816.

40. Kilic R, Safak MA, Ozdek A, Gocmen H, Kilic D, Samim E. Effect of 23 valent pneumococcal polysaccharide and Haemophilus influenza conjugated vaccines on the clinical course of otitis media with effusion. Laryngoscope 2002; 112: 2042-2045.

41. Marchisio P, Cavagna R, Maspes B, et al. Efficacy of intranasal virosomal influenza vaccine in the prevention of recurrent acute otitis media in children. Clin Infect Dis 2002; 35: 168-174.

42. Sugiura Y, Ohashi Y, Nakai Y. The herbal medicine, sairei-to, prevents endotoxin-induced otitis media with effusion in the guinea pig. Acta Otolaryngol Suppl 1997; 531: 21-33.

43. Jeong HJ, Hong SH, Kim SC, et al. Effects of Allergina on the treatment of otitis media with effusions. Inflammation 2002; 26: 89-95.

44. Harrison H, Fixsen A, Vickers A. A randomized comparison of homoeopathic and standard care for the treatment of glue ear in children. Complement Ther Med 1999; 7: 132-135.

45. Jacobs J, Springer DA, Crothers D. Homeopathic treatment of acute otitis media in children: a preliminary randomized placebo-controlled trial. Pediatr Infect Dis J 2001; 20: 177-183.

46. Moller P, Dalen H. Middle ear mucosa in cleft palate children. A scanning electron microscopic study. Acta Otolaryngol Suppl 1979, 360: $198-203$

47. Meyerhoff WL, Giebink GS. Panel discussion: pathogenesis of otitis media. Pathology and microbiology of otitis media. Laryngoscope 1982; 92: $273-277$.

48. Tanaka K, Saito J, Ohashi M, Terayama Y. Histopathology of otitis media with effusion. An electron microscopic study of human temporal bones. Arch Otorbinolaryngol 1986; 243: 269-273.

49. Goycoolea MV. Gland formation in otitis media. An ultrastructural study in humans. Acta Otolaryngol 2001; 121: 182-184.

50. Tos M, Caye-Thomasen P. Mucous glands in the middle ear-what is known and what is not. ORL J Otorbinolaryngol Relat Spec 2002; 64: 86-94.

51. FitzGerald JE, Green GG, Birchall JP, Pearson JP. Rheologic studies on middle ear effusions and their mucus glycoproteins. Arch Otolaryngol Head Neck Surg 1989; 115: 462-468.

52. Carrie S, Hutton DA, Birchall JP, Green GG, Pearson JP. Otitis media with effusion: components which contribute to the viscous properties. Acta Otolaryngol 1992; 112: 504-511.

53. Lin J, Tsuprun V, Kawano H, et al. Characterization of mucins in human middle ear and Eustachian tube. Am J Physiol Lung Cell Mol Physiol 2001; 280: L1157-L1167.
54. Hutton DA, Fogg FJ, Murty G, Birchall JP, Pearson JP. Preliminary characterization of mucin from effusions of cleft palate patients. Otolaryngol Head Neck Surg 1993; 109: 1000-1006.

55. Hutton DA, Fogg FJ, Kubba H, Birchall JP, Pearson JP. Heterogeneity in the protein cores of mucins isolated from human middle ear effusions: evidence for expression of different mucin gene products. Glycoconj $J$ 1998; 15: 283-291

56. Sone M, Paparella MM, Schachern PA, Morizono N, Le CT, Lin J. Expression of glycoconjugates in human eustachian tubes with otitis media. Laryngoscope 1998; 108: 1474-1479.

57. Takeuchi K, Yagawa M, Ishinaga H, Kishioka C, Harada T, Majima Y. Mucin gene expression in the effusions of otitis media with effusion. Int J Pediatr Otorhinolaryngol 2003; 67: 53-58.

58. Hutton DA, Guo L, Birchall JP, Severn TL, Pearson JP. MUC5B expression in middle ear mucosal glands. Biochem Soc Trans 1998; 26: $\mathrm{S} 117$.

59. Kawano H, Paparella MM, Ho SB, et al. Identification of MUC5B mucin gene in human middle ear with chronic otitis media. Laryngoscope 2000; 110: 668-673.

60. Chung MH, Choi JY, Lee WS, Kim HN, Yoon JH. Compositional difference in middle ear effusion: mucous versus serous. Laryngoscope 2002; 112: $152-155$.

61. Smirnova MG, Birchall JP, Pearson JP. In vitro study of IL-8 and goblet cells: possible role of IL-8 in the aetiology of otitis media with effusion. Acta Oto-Laryngol 2002; 122: 146-152.

62. Smirnova MG, Kiselev SL, Birchall JP, Pearson JP. Up-regulation of mucin secretion in HT29-MTX cells by the pro-inflammatory cytokines TNF- $\alpha$ and IL-6. Eur Cytokine Network 2001; 12: 119-125.

63. Liederman EM, Post JC, Aul JJ, et al. Analysis of adult otitis media: polymerase chain reaction versus culture for bacteria and viruses. Ann Otol Rhinol Laryngol 1998; 107: 10-16.

64. Murphy TF. Bacterial otitis media: pathogenetic considerations. Pediatr Infect Dis I 2000, (5 Suppl): S9-S15, discussion S15-S16.

65. Shaw CB, Obermyer N, Wetmore SJ, Spirou GA, Farr RW. Incidence of adenovirus and respiratory syncytial virus in chronic otitis media with effusion using the polymerase chain reaction. Otolaryngol Head Neck Surg 1995; 113: 234-241.

66. Pitkaranta A, Jero J, Arruda E, Virolainen A, Hayden FG. Polymerase chain reaction-based detection of rhinovirus, respiratory syncytial virus, and coronavirus in otitis media with effusion. J Pediatr 1998; 133: $390-394$

67. Bernstein JM, Doyle WJ. Role of IgE-mediated hypersensitivity in otitis media with effusion: pathophysiologic considerations. Ann Otol Rhinol Laryngol Suppl 1994; 163: 15-19.

68. Bernstein JM. Role of allergy in eustachian tube blockage and otitis media with effusion: a review. Otolaryngol Head Neck Surg 1996; 114: $562-568$.

69. Tasker A, Dettmar PW, Panetti M, Koufman JA, Birchall JP, Pearson JP. Reflux of gastric juice and glue ear in children. Lancet 2002; 359: 493

70. Tasker A, Dettmar PW, Panetti M, Koufman JA, Birchall JP, Pearson JP. Is gastric reflux a cause of otitis media with effusion in children? Laryngoscope 2002; 112: 1930-1934.

71. Poelmans J, Tack J, Feenstra L. Prospective study on the incidence of chronic ear complaints related to gastroesophageal reflux and on the outcome of antireflux therapy. Ann Otol Rhinol Laryngol 2002; 111: 933-938.

72. Miller AJ, Gianoli GJ. Eustachian tube dysfunction. J La State Med Soc 1996; 148: 329-333

73. Takasaki K, Sando I, Balaban CD, Ishijima K. Postnatal development of eustachian tube cartilage. A study of normal and cleft palate cases. Int I Pediatr Otorbinolaryngol 2000; 52: 31-36.

74. Linder TE, Marder HP, Munzinger J. Role of adenoids in the pathogenesis of otitis media: a bacteriologic and immunohistochemical analysis. Ann Otol Rhinol Laryngol 1997; 106: 619-623.

75. Jung TT, Juhn SK. Prostaglandins and other arachidonic acid metabolites in the middle ear fluids. Auris Nasus Larynx 1985; 12: S148-S150.

76. Jung TT. Prostaglandins, leukotrienes, and other arachidonic acid metabolites in the pathogenesis of otitis media. Laryngoscope 1988; 98 : $980-993$.

77. Stenfors LE, Albiin N, Bloom GD, Hellstrom S, Widemar L. Mast cells and middle ear effusion. Am J Otolaryngol 1985; 6: 217-219.

78. Skoner DP, Stillwagon PK, Casselbrandt ML, Tanner EP, Doyle WJ, Fireman P. Inflammatory mediators in chronic otitis media with effusion. Arch Otolaryngol Head Neck Surg 1988; 114: 1131-1133.

79. Furukawa M, Kubo N, Yamashita T. Biochemical evidence of plateletactivating factor (PAF) in human middle ear effusions. Laryngoscope 1995; 105: 188-191

80. Okamoto Y, Kudo K, Ishikawa K, et al. Presence of respiratory syncytial virus genomic sequences in middle ear fluid and its relationship to expression of cytokines and cell adhesion molecules. I Infect Dis 1993; 168: 1277-1281

81. Bundo J, Watanabe N, Yoshida K, Mogi G. Study on adhesion factors in lymphocyte migration to the middle ear mucosa. Ann Otol Rhinol Laryngol 1996; 105: 795-803. 
82. Himi T, Kamimura M, Kataura A, Imai K. Quantitative analysis of soluble cell adhesion molecules in otitis media with effusion. Acta Otolaryngol 1994; 114: 285-288.

83. Ohashi Y, Nakai Y, Tanaka A, Kakinoki Y, Washio Y. Soluble adhesion molecules in middle ear effusions from patients with chronic otitis media with effusion. Clin Otolaryngol 1998; 23: 231-234.

84. Schousboe LP, Rasmussen LM, Ovesen T. RANTES in otitis media with effusion: presence, role and correlation with cytokines and microbiology. APMIS 2001; 109: 441-446.

85. Narkio-Makela M, Teppo AM, Meri S. Complement C3 cleavage and cytokines interleukin-1beta and tumor necrosis factor-alpha in otitis media with effusion. Laryngoscope 2000; 110: 1745-1749.

86. Pitkaranta A, Hovi T, Karma P. Interferon production by leukocytes in children with otitis media with effusion. Int J Pediatr Otorbinolaryngol 1996; 34: 25-33.

87. Smirnova MG, Kiselev SL, Gnuchev NV, Birchall JP, Pearson JP. Role of the pro-inflammatory cytokines tumor necrosis factor-alpha, interleukin- 1 beta, interleukin- 6 and interleukin- 8 in the pathogenesis of the otitis media with effusion. Eur Cytokine Network 2002; 13: 161-172.

88. Yellon RF, Leonard G, Marucha PT, et al. Characterization of cytokines present in middle ear effusions. Laryngoscope 1991; 101: 165-169.

89. Brooks EG, Schmalstieg FC, Wirt DP, et al. A novel X-linked combined immunodeficiency disease. J Clin Invest 1990; 86: 1623-1631.

90. Bernstein JM, Park BH. Defective immunoregulation in children with chronic otitis media with effusion. Otolaryngol Head Neck Surg 1986; 94: $334-339$

91. Bernstein JM, Rich GA, Odziemiec C, Ballow M. Are thymus-derived lymphocytes ( $\mathrm{T}$ cells) defective in the nasopharyngeal and palatine tonsils of children? Otolaryngol Head Neck Surg 1993; 109: 693-700.

92. Bernstein JM, Ballow M, Xiang S, O'Neil K. Th1/Th2 cytokine profiles in the nasopharyngeal lymphoid tissues of children with recurrent otitis media. Ann Otol Rhinol Laryngol 1998; 107: 22-27.

93. Bikhazi P, Ryan AF. Expression of immunoregulatory cytokines during acute and chronic middle ear immune response. Laryngoscope 1995; 105: 629-634

94. Catanzaro A, Ryan A, Batcher S, Wasserman SI. The response to human rIL-1, rIL-2, and rTNF in the middle ear of guinea pigs. Laryngoscope 1991; 101: $271-275$.

95. Kubo T, Anniko M, Stenqvist M, Hsu W. Interleukin-2 affects cochlear function gradually but reversibly. ORL J Otorbinolaryngol Relat Spec 1998; 60: $272-277$.

96. Gloddek B, Lamm K, Haslov K. Influence of middle ear immune response on the immunological state and function of the inner ear. Laryngoscope 1992; 102: 177-181.

97. Skotnicka B, Hassmann E. Cytokines in children with otitis media with effusion. Eur Arch Otorhinolaryngol 2000; 257: 323-326.

98. Jyonouchi H, Sun S, Le H, Rimell FL. Evidence of dysregulated cytokine production by sinus lavage and peripheral blood mononuclear cells in patients with treatment-resistant chronic rhinosinusitis. Arch Otolaryngol Head Neck Surg 2001; 127: 1488-1494.

99. Hebda PA, Alper CM, Doyle WJ, Burckart GJ, Diven WF, Zeevi A. Upregulation of messenger RNA for inflammatory cytokines in middle ear mucosa in a rat model of acute otitis media. Ann Otol Rhinol Laryngol 1998; 107: 501-507.

100. Hebda PA, Piltcher OB, Swarts JD, Alper CM, Zeevi A, Doyle WJ. Cytokine profiles in a rat model of otitis media with effusion caused by eustachian tube obstruction with and without Streptococcus pneumoniae infection. Laryngoscope 2002; 112: 1657-1662.

101. Kita H, Himi T. Cytokine and chemokine induction using cell wall component and toxin derived from gram-positive bacteria in the rat middle ear. Acta Otolaryngol 1999; 119: 446-452.

102. Melhus A, Ryan AF. Expression of cytokine genes during pneumococcal and nontypeable Haemophilus influenzae acute otitis media in the rat. Infect Immun 2000; 68: 4024-4031.

103. Melhus A. Effects of amoxicillin on the expression of cytokines during experimental acute otitis media caused by non-typeable Haemophilus influenzae. J Antimicrob Chemother 2001; 48: 397-402.

104. Kurono Y, Suzuki M, Mogi G, et al. Effects of intranasal immunization on protective immunity against otitis media. Int J Pediatr Otorbinolaryngol 1999; 49(Suppl 1): S227-S229.

105. Cooter MS, Eisma RJ, Burleson JA, Leonard G, Lafreniere D, Kreutzer DL. Transforming growth factor-beta expression in otitis media with effusion. Laryngoscope 1998; 108: 1066-1070.

106. Somers T, Goovaerts G, Schelfhout L, Peeters S, Govaerts PJ, Offeciers E. Growth factors in tympanic membrane perforations. Am J Otol 1998; 19: $428-434$

107. Shuto T, Xu H, Wang B, et al . Activation of NF-kappa B by nontypeable Hemophilus influenzae is mediated by toll-like receptor 2-TAK1dependent NIK-IKK alpha/beta-I kappa B alpha and MKK3/6-p38 MAP kinase signaling pathways in epithelial cells. Proc Natl Acad SCi USA 2001; 98: 8774-8779.

108. Jono H, Xu H, Kai H, et al. Transforming growth factor-beta-Smad signaling pathway negatively regulates nontypeable Haemophilus influenzae-induced MUC5AC mucin transcription via mitogen-acti- vated protein kinase (MAPK) phosphatase-1-dependent inhibition of p38 MAPK. I Biol Chem 2003; 278: 27811-27819.

109. Jang CH, Kim YH. Characterization of cytokines present in pediatric otitis media with effusion: comparison of allergy positive and negative. Int J Pediatr Otorhinolaryngol 2002; 66: 37-40.

110. Sobol SE, Taha R, Schloss MD, et al. T(H)2 cytokine expression in atopic children with otitis media with effusion. J Allergy Clin Immunol 2002; 110: $125-130$

111. Astrom K, Magnusson CG, Papatziamos G, Hemlin C, Scheynius A, van der Ploeg I. Analysis of epsilon germline transcripts and IL-4 mRNA expression in the adenoids suggests local IgE switching. Allergy 2000; 55: $1049-1055$.

112. Pollock HW, Ebert CS, Dubin MG, White DR, Prazma J, Pillsbury HC 3 rd. The role of soluble interleukin- 4 receptor and interleukin-5 antibody in preventing late-phase allergy-induced eustachian tube dysfunction. Otolaryngol Head Neck Surg 2002; 127: 169-176.

113. Dabbagh K, Takeyama K, Lee HM, Ueki IF, Lausier JA, Nadel JA. IL-4 induces mucin gene expression and goblet cell metaplasia in vitro and in vivo. J Immunol 1999; 162: 6233-6237.

114. Jayawickreme SP, Gray T, Nettesheim P, Eling T. Regulation of 15lipoxygenase expression and mucus secretion by IL- 4 in human bronchial epithelial cells. Am J Physiol 1999; 276: L596-L603.

115. Seong JK, Koo JS, Lee WJ, et al. Upregulation of MUC8 and downregulation of MUC5AC by inflammatory mediators in human nasal polyps and cultured nasal epithelium. Acta Otolaryngol 2002; 122: $401-407$

116. Wright ED, Hurst D, Miotto D, Giguere C, Hamid Q. Increased expression of major basic protein (MBP) and interleukin-5(IL-5) in middle ear biopsy specimens from atopic patients with persistent otitis media with effusion. Otolaryngol Head Neck Surg 2000; 123: 533-538.

117. Nonaka M, Fukumoto A, Ozu C, et al. IL-5 and eotaxin levels in middle ear effusion and blood from asthmatics with otitis media with effusion. Acta Otolaryngol 2003; 123: 383-387.

118. Himi T, Suzuki T, Kodama H, Takezawa H, Kataura A. Immunologic characteristics of cytokines in otitis media with effusion. Ann Otol Rbinol Laryngol Suppl 1992; 157: 21-25.

119. Nutku E, Aizawa H, Hudson SA, Bochner BS. Ligation of Siglec-8: a selective mechanism for induction of human eosinophil apoptosis. Blood 2003; 101: 5014-5020.

120. Lang RW, Liu YS, Lim DJ, Birck HG. Antimicrobial factors and bacterial correlation in chronic otitis media with effusion. Ann Otol Rhinol Laryngol 1976; 85: 145-151.

121. Liu YS, Lim DJ, Lang RW, Birck HG. Chronic middle ear effusions Immunochemical and bacteriological investigations. Arch Otolaryngol 1975; 101: 278-286.

122. Jones EA Jr,, Thomas LR, Davis NC. The significance of secretory IgA in middle ear fluid. Ann Allergy 1979; 42: 236-240.

123. Lewis DM, Schram JL, Lim DJ, Birck HG, Gleich G. Immunoglobulin E in chronic middle ear effusions: comparison of RIST, PRIST, and RIA techniques. Ann Otol Rhinol Laryngol 1978; 87: 197-201.

124. Lim DJ, Liu YS, Schram J, Birck HG. Immunoglobulin E in chronic middle ear effusions. Ann Otol Rhinol Laryngol 1976; 85: 117-123.

125. Bernstein JM, Lee J, Conboy K, Ellis E, Li P. Further observations on the role of IgE-mediated hypersensitivity in recurrent otitis media with effusion. Otolaryngol Head Neck Surg 1985; 93: 611-615.

126. Yamanaka N, Somekawa Y, Suzuki T, Kataura A. Immunologic and cytologic studies in otitis media with effusion. Acta Otolaryngol 1987; 104: $481-486$

127. Yamanaka N, Somekawa Y, Himi T, Suzuki T, Kataura A. Immune complexes in otitis media with effusion. Auris Nasus Larynx 1985; 12(Suppl 1): $S 70-S 72$.

128. Lewis DM, Schram JL, Birck HG, Lim DJ. Antibody activity in otitis media with effusion. Ann Otol Rhinol Laryngol 1979; 88: 392-396.

129. Takada R, Harabuchi Y, Himi T, Kataura A. Antibodies specific to outer membrane antigens of Moraxella catarrhalis in sera and middle ear effusions from children with otitis media with effusion. Int $J$ Pediatr Otorbinolaryngol 1998; 46: 185-195.

130. Stenfors LE, Raisanen S. Secretory IgA- and IgG-coated bacteria in chronically discharging ears. J Laryngol Otol 1991; 105: 515-517.

131. Stenfors LE, Raisanen S. Immunoglobulin-coated bacteria in effusions from secretory and chronic suppurative otitis media. Am J Otolaryngol 1991; 12: $161-164$

132. Yamaguchi T, Urasawa T, Kataura A. Secretory immunoglobulin A antibodies to respiratory viruses in middle ear effusion of chronic otitis media with effusion. Ann Otol Rhinol Laryngol 1984; 93: 73-75.

133. Sloyer JL Jr, Ploussard JH, Karr LJ. Otitis media in the young infant: an IgE-mediated disease? Ann Otol Rhinol Laryngol Suppl 1980; 89: 133137.

134. Boedts D, De Groote G, Van Vuchelen J. Atopic allergy and otitis media with effusion. Acta Otolaryngol Suppl 1984; 414: 108-114.

\section{Accepted 11 February 2004}




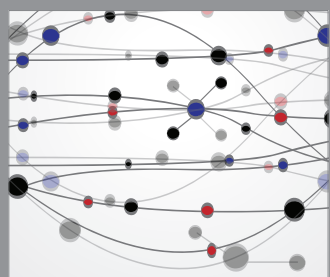

The Scientific World Journal
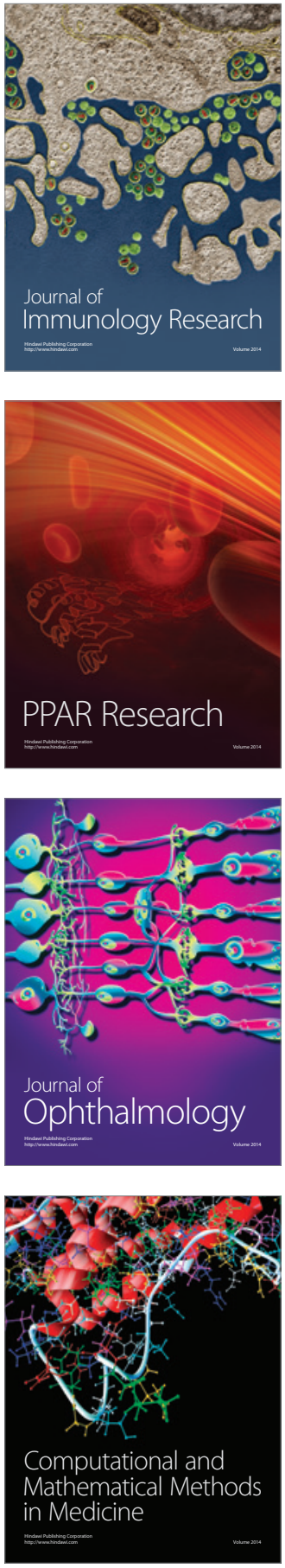

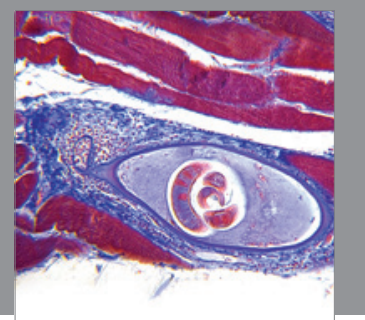

Gastroenterology

Research and Practice
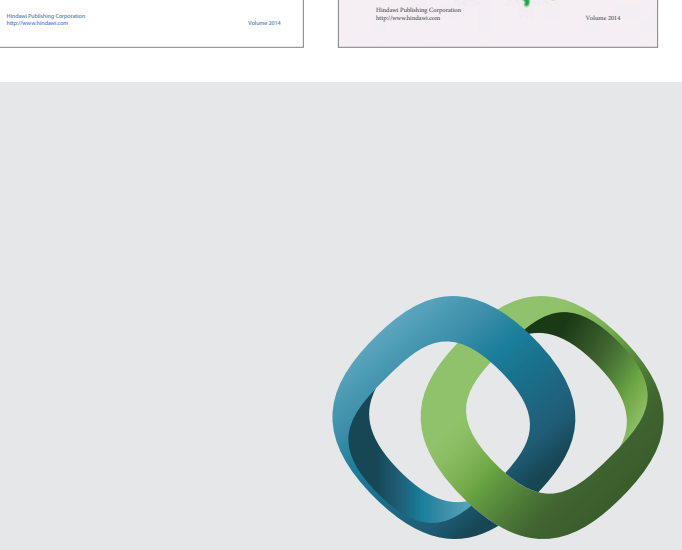

\section{Hindawi}

Submit your manuscripts at

http://www.hindawi.com
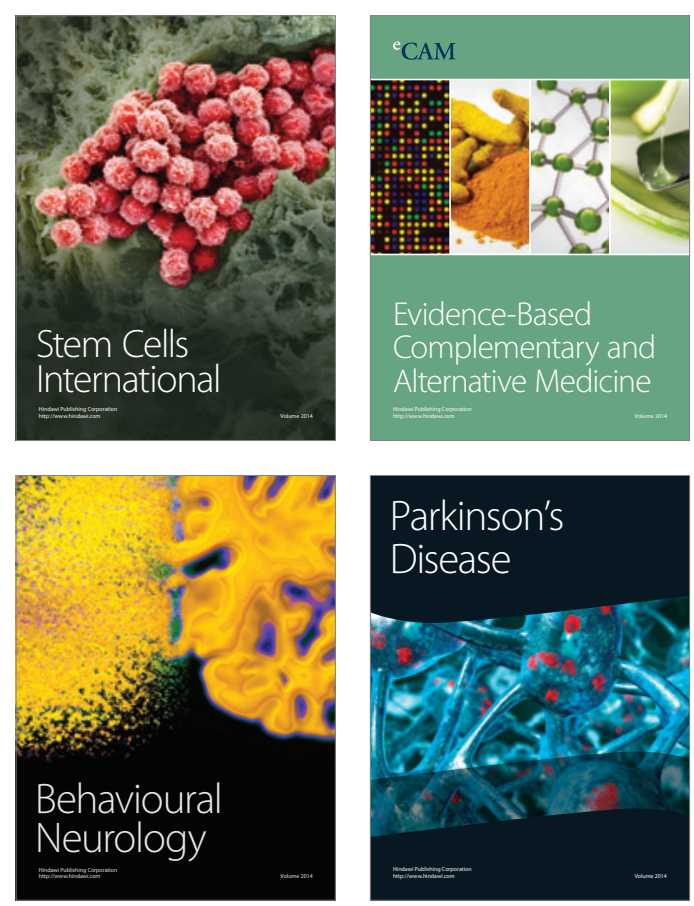

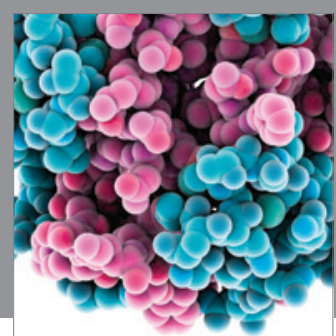

Journal of
Diabetes Research

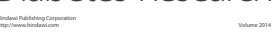

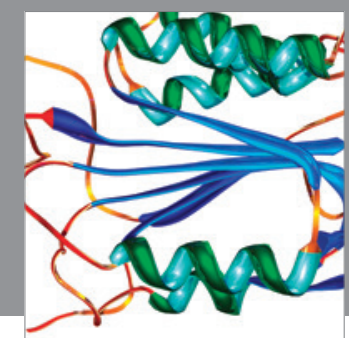

Disease Markers
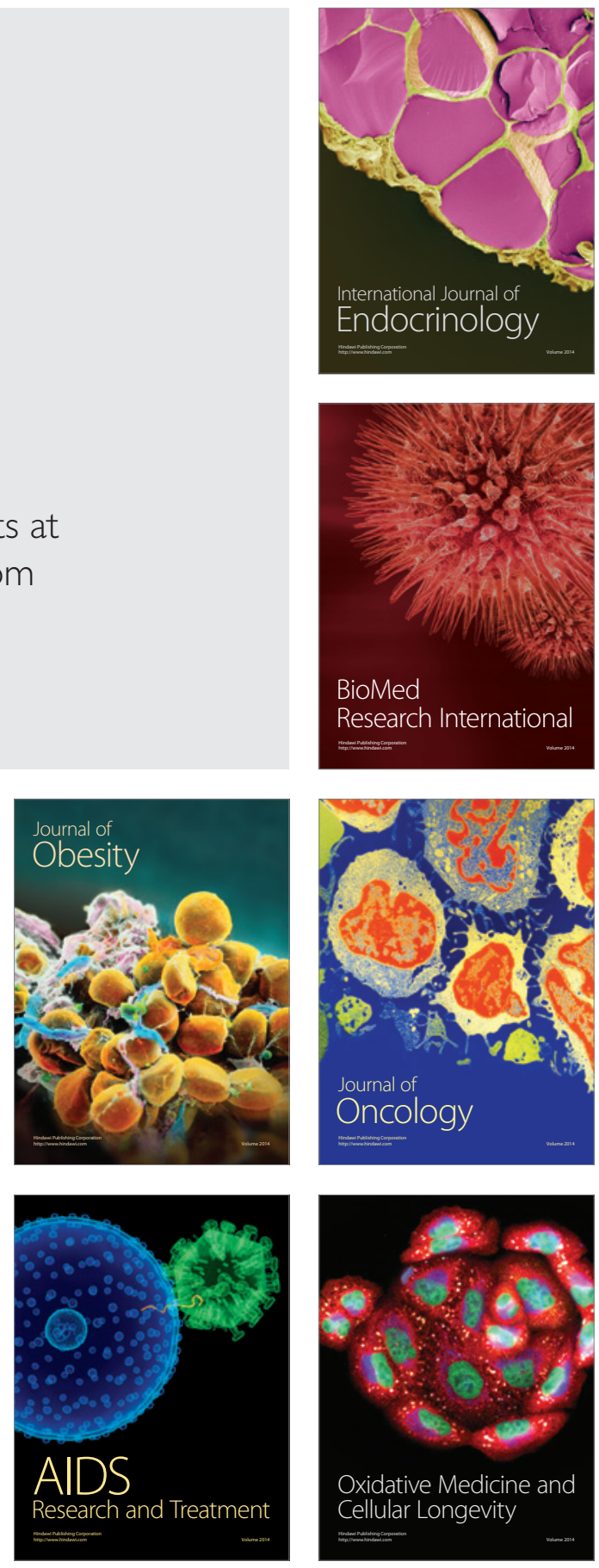